\title{
REVIEW LITERATURE: MENGKAJI FAKTOR-FAKTOR YANG BERHUBUNGAN DENGAN RENDAHNYA MINAT IBU TERHADAP PENGGUNAAN METODE KONTRASEPSI JANGKA PANJANG (MKJP)
}

\author{
Ajeng Arianne Fikri ${ }^{1}$, Is Susiloningtyas ${ }^{2}$ \\ Program Studi Kebidanan Sarjana Kebidanan dan Pendidikan Profesi Bidan Fakultas Kedokteran \\ Universitas Islam Sultan Agung Semarang ${ }^{12}$ \\ e-mail: ${ }^{1}$ ajengarianne@gmail.com, ${ }^{2}$ susiloningtyas@unissula.ac.id
}

\begin{abstract}
Introduction: MKJP is a contraceptive tool to delay, spacing pregnancy and stop fertility which is used in the long term. In addition, MKJP is more rational and has few side effects. The 2019 National Health Profile data shows the results of the achievements of active family planning participants per contraceptive device as follows; IUD is $7.40 \%$, MOW $2.70 \%$, MOP $0.50 \%$, implant $7.40 \%$, condom $1.20 \%$, injection $63.70 \%$, and pill $17.00 \%$. This data shows that short-term contraception is the community's top choice (Ministry of Health, 2019). Method: International literature was traced through electronic media with keyword guidance. Eight articles were selected, each of which represented the factors associated with the low interest of mothers in using various long-term contraceptive methods (Mkjp). Results: There were differences in the motivation of mothers in choosing contraceptives such as mother, occupation, exposure to information sources of MKJP and types of non-MKJP contraception. Discussion: One of the factors that most influences the choice of long-term contraceptives (MKJP) is the level of knowledge of pregnant women, especially for the middle to lower class. Conclusion: The conclusion based on the analysis that has been done is to determine the factors associated with the low interest of mothers in the use of long-term contraceptive methods (Mkjp).
\end{abstract}

Keywords: MKJP, Interests, Family Planning acceptors

ABSTRAK

Pendahuluan: MKJP adalah alat kontrasepsi untuk menunda, menjarangkan kehamilan serta menghentikan kesuburan yang digunakan dalam jangka panjang. Selain itu, MKJP lebih rasional dan mempunyai efek samping sedikit. Data Profil Kesehatan Nasional Tahun 2019 didapatkan hasil pencapaian peserta KB aktif per alat kontrasepsi sebagai berikut ; IUD 7,40\%, MOW 2,70\%, MOP 0,50\%, implan $7,40 \%$, kondom $1,20 \%$, suntik $63,70 \%$, dan pil $17,00 \%$. Data tersebut menunjukkan bahwa kontrasepsi jangka pendek menjadi pilihan utama masyarakat (Kementerian Kesehatan RI, 2019). Metode: Literatur mancanegara ditelusuri melalui sarana media elektronik dengan penuntun kata kunci. Artikel terseleksi sejumlah 8, yang masing- masing mewakili faktor-faktor Yang Berhubungan Dengan Rendahnya Minat Ibu Terhadap Penggunaan Metode Kontrasepsi Jangka Panjang (MKJP) yang bervariatif. Hasil: Adanya perbedaan motivasi ibu dalam memilih alat kontrasepsi seperti, ibu, pekerjaan, paparan sumber informasi MKJP dan jenis kontrasepsi Non-MKJP. Pembahasan: Salah satu faktor yang paling mempengaruhi pemilihan alat kontrasepsi jangka Panjang (MKJP) adalah tingkat pengetahuan ibu hamil khususnya bagi kalangan menengah ke bawah. Kesimpulan: Simpulan berdasarkan analisa yang telah dilakukan adalah untuk mengetahui faktor-faktor Yang Berhubungan Dengan Rendahnya Minat Ibu Terhadap Penggunaan Metode Kontrasepsi Jangka Panjang (MKJP).

Kata kunci: MKJP, Minat, Akseptor KB

\section{PENDAHULUAN}

\section{Latar Belakang}

Pelayanan Kontrasepsi adalah serangkaian kegiatan meliputi pemberian KIE, konseling, penapisan kelayakan medis, pemberian kontrasepsi, pemasangan atau pencabutan, dan penanganan efek samping atau komplikasi dalam upaya mencegah kehamilan. Pelayanan kontrasepsi yang diberikan meliputi kondom, pil, suntik, pemasangan atau pencabutan implan, pemasangan atau pencabutan alat kontrasepsi dalam rahim, pelayanan tubektomi, dan pelayanan vasektomi. KB Pascapersalinan (KBPP) adalah pelayanan KB yang diberikan kepada PUS setelah persalinan sampai kurun waktu 42 hari, dengan tujuan untuk menjarangkan kehamilan, atau mengakhiri kesuburan [1]. 


\section{Vol. 16 No.2 Mei - Agustus 2021}

Beberapa studi menunjukkan pelayanan $\mathrm{KB}$ (termasuk KBPP) yang efektif dapat mengurangi kematian ibu dengan cara mengurangi kehamilan dan mengurangi kelahiran risiko tinggi. Indonesia merupakan salah satu negara berkembang di dunia yang mengalami peningkatan pertumbuhan penduduk di setiap tahunnya. Hasil perhitungan jumlah penduduk pasangan usia subur di tahun 2019 sebanyak 38.690.214 jiwa dengan persentase KB suntik sebanyak 15.419.826 (63,7\%) [1].

KB aktif di antara PUS tahun 2019 sebesar $62,5 \%$, mengalami penurunan dari tahun sebelumnya 2018 yaitu sebesar 63,27\% [1]. Semakin tinggi angka prevalensi KB di suatu negara maka semakin rendah proporsi kematian ibu di negara tersebut, Sejalan dengan hal tersebut, terjadi juga hubungan yang erat antara KB dengan angka fertilitas total (total fertility rate/TFR). TFR yaitu jumlah rata-rata anak yang dilahirkan oleh seorang perempuan pada akhir masa reproduksinya. Sehingga dapat disimpulkan bahwa KB merupakan hal yang berpengaruh terhadap TFR. Semakin tinggi angka prevalensi KB maka semakin rendah TFR suatu negara. Dengan demikian KB merupakan hal utama dalam upaya menurunkan angka kematian ibu di dunia termasuk juga di Indonesia [2].

MKJP adalah alat kontrasepsi untuk menunda, menjarangkan kehamilan serta menghentikan kesuburan yang digunakan dalam jangka panjang. Selain itu, MKJP lebih rasional dan mempunyai efek samping sedikit. Manfaat dari MKJP yaitu efektif mencegah kehamilan hingga 99\%, jangka waktu pemakaian lebih lama, biaya terjangkau, tidak mempengaruhi produksi air susu ibu, tidak ada perubahan fungsi seksual, merencanakan kehamilan dan masa depan anak dan mencegah resiko kematian ibu saat melahirkan [3].

Data Profil Kesehatan Nasional Tahun 2019 didapatkan hasil pencapaian peserta $\mathrm{KB}$ aktif per alat kontrasepsi sebagai berikut ; IUD 7,40\%, MOW $2,70 \%$, MOP $0,50 \%$, implan 7,40 \%, kondom 1,20\%, suntik 63,70 \%, dan pil 17,00\%. Data tersebut menunjukkan bahwa kontrasepsi jangka pendek menjadi pilihan utama masyarakat [1].

Studi pendahuluan yang dilakukan tahun 2015 didapatkan hasil 6 dari 8 responden menggunakan metode kontrasepsi jangka pendek. Sebagian besar responden mengatakan tidak memilih MKJP karena takut dengan prosedur pemasangan kontrasepsi serta takut efek samping setelah pemakaian, berupa nyeri dan menstruasi yang banyak pada IUD dan nyeri pada pemasangan dan pelepasan pada implan. Kondisi ini terjadi karena pengetahuan masyarakat akan MKJP yang masih kurang untuk mendukung keikutsertaan MKJP. Penatalaksanaan yang tepat untuk meningkatkan keikutsertaan MKJP dengan kondisi tersebut adalah melalui peningkatan pengetahuan akseptor tentang MKJP, karena pengetahuan merupakan domain yang sangat penting untuk terbentuknya tindakan seseorang [4].

Terdapat berbagai faktor yang mempengaruhi pemakaian MKJP yang rendah, diantaranya bersumber dari pengguna pelayanan maupun penyedia layanan. Berbagai upaya telah dilakukan oleh BKKBN dalam rangka meningkatkan mutu pelayanan KB. Diantaranya, pelatihan CTU untuk tenaga kesehatan, pelatihan KIP/ Konseling dengan menggunakan ABPK, serta meningkatkan sarana penunjang pelayanan MKJP [3].

Upaya peningkatan akseptor mengenai MKJP

dapat dilakukan dengan penyuluhan maupun konseling yang interaktif sehingga diharapkan dapat meningkatkan minat akseptor menggunakan MKJP. Berdasarkan pendahuluan tersebut maka peneli perlu melakukan penelitian tentang " Faktor-Faktor Yang Berhubungan Dengan Rendahnya Minat Ibu Terhadap Penggunaan Metode Kontrasepsi Jangka Panjang (MKJP)".

\section{METODE PENELITIAN}

Dalam penelitian ini dilakukan pencarian literatur melalui media, Medline, DOAJ (Directory of Open Access Journals), BioMed Central, dan WHO regional databases. Tujuan dari artikel ini adalah yang mengulas masalah desminorea. Kata kunci yang dipakai untuk penelusuran literatur yaitu "Factors of Mother's low Interest Associated in the Use of LongTerm Contraceptive Methods (MKJP)" . Cara yang digunakan dalam mencari artikel menggunakan bahasa Inggris dan Indonesia yang relevan dengan topik.

Pencarian dilakukan dengan menggunakan beberapa database antara lain Google Scholar, Proquest dan Science Direct. Keyword yang digunakan adalah "Factors of Mother's low Interest Associated", "Long-Term Contraceptive Methods (MKJP)", "Faktor-Faktor yang mempengaruhi minat ibu terhadap MKJP". Artikel yang diperoleh di review untuk memilih artikel yang sesuai dengan kriteria dan didapatkan 8 artikel yang terdiri dari 5 artikel internasional dan 3 artikel nasional yang selanjutnya akan di review.

Artikel Penelitian yang diteliti oleh [5] yang berjudul "Factors Affecting of Used Long Contraception Method to Women Reproductive at Public Health Centre Limau Asri Mimika Regency". menggunakan metode oservasional analitik dengan pendekatan cross sectional. Jumlah sampel 92 responden dengan purposive sampling. Data diperoleh dengan menggunakan kuesioner dan dianalisis menggunakan Uji Chi Square.

Artikel Penelitian yang diteliti oleh [6] yang berjudul "Dominant factors on selection of contraception toward new family planning acceptors in public health center area in Padang" menggunakan metode oservasional analitik dengan pendekatan cross 
sectional. Populasi dalam penelitian ini adalah akseptor KB baru dengan jumlah sampel 114 orang. Teknik pengambilan sampel secara acak didasarkan pada kelompok individu. Kriteria inklusi di Penelitian ini merupakan pasangan yang baru memakai KB sedangkan kriteria eksklusi adalah pasangan yang tidak diinginkan diwawancarai tiga kali. Peserta diberi informasi persetujuan untuk persetujuan etis dalam penelitian ini. Data dikumpulkan termasuk jenis kontrasepsi, usia, tingkat pendidikan, paritas, status pekerjaan, dalam bentuk kategori. Proses pengumpulan data dilakukan dengan caradari responden yang mengisi kuesioner yang disediakan. Analisis data dilakukan dengan program SPSS 10.07. Itu Model analisis data yang digunakan adalah uji chi-square. Dengan demikian, dalam memberikan kesimpulan dalam penelitian ini, yaitu faktor dominannya adalah dukungan suami. karena, suami adalah yang paling dipatuhi dalam keluarga. Ini adalah budaya timur dan masih kental di wilayah Padang.

Artikel Penelitian yang diteliti oleh [7] yang berjudul "The Factors Affecting to Selection of Long Term Contraception Method in Lush Age Couples in Prafi Health Primary Manokwari District West Papua Province" menggunakan metode Penelitian menggunakan metode kuantitatif dalam penelitian ini termasuk dalam kategorip enelitian korelasi. Definisi penelitian korelasi menurut Arikunto (2010) adalah penelitian yang dilakukan oleh peneliti kepada tentukan tingkat hubungan antara keduanya atau lebih banyak variabel, tanpa membuat perubahan, penambahan, atau manipulasi data itu sudah ada. Penelitian ini menggunakan Desain studi sectional yaitu pengumpulan data dilakukan secara bersamaan sekaligus waktu (Swarjana, 2013). Sampel adalah bagian dari bilangan dan karakteristik yang dimiliki oleh penduduk (Sugiyono, 2013). Sampel adalah bagian atau perwakilan dari populasi yang diteliti. Itu Besar sampel dalam penelitian ini adalah 68 dan di analisis menggunakan Uji Chi Square. Kesimpulan Ada pengaruh pengetahuan dan fasilitas kesehatan dengan pemilihan alat kontrasepsi jangka Panjang untuk pasangan Usia subur.

Artikel Penelitian yang diteliti oleh [8] yang berjudul "The Influence Of Health Education Toward The Level Of Knowledge And Motivation In The Use Of Family Planning Programs With The Long-Term Method Of Contraception" menggunakan metode Penelitian ini menggunakan analisis korelasi One Group Pretest and Postest dengan pendekatan cross sectional dan pengambilan sampel menggunakan metode Systematic Random Sampling. Itu Responden yang digunakan sebanyak 80 orang. Pengumpulan data dilakukan dengan instrumen kuesioner dan data dianalisis secara bivariat dengan menguji Marginal Homogeneity dan McNemar. Kesimpulan Ada motifasi dengan pemilihan alat kontrasepsi jangka Panjang untuk pasangan Usia subur.

Artikel Penelitian yang diteliti oleh [9] yang berjudul "The Factors Correlating to the Usage of
Long-Term Contraception Method (MKJP) Especially IUD in the Domain of Society Health Center Simpang Baru Pekanbaru City" menggunakan metode Teknik pengambilan sampel dengan menggunakan teknik sampling acak sistematis metode. Instrumen yang digunakan dalam penelitian ini adalah angket pengetahuan, pasangan dukungan, dan budaya. Pengolahan data menggunakan komputer melalui empat tahap mereka adalah pengeditan, pengkodean, pemrosesan, dan pembersihan. Data yang terkumpul kemudian dianalisis dengan univariat, bivariat, dan multivariat menggunakan uji chi square. Kesimpulan Ada hubungan antara pengetahuan, dukungan pasangan, dan budaya dengan penggunaan Metode Kontrasepsi Jangka Panjang (MKJP) khususnya IUD di Wilayah Kerja Puskesmas Simpang Kota Pekanbaru Baru .

Artikel Penelitian yang diteliti oleh [10] yang berjudul "Faktor - Faktor Yang Berhubungan Dengan Rendahnya Minat Ibu Tentang Penggunaan Metode Kontrasepsi Jangka Panjang Pada Kawasan Pesisir Desa Luhu Kecamatan Huamual Kabupaten Seram Bagian Barat" menggunakan metode Penelitian ini merupakan peneliti observasi analitik dengan metode croos sectional study penelitian ini di gunakan dengan metode Purposive Sampling yang berjumlah sampel 54 responden. Istrumen penelitian ini menggunakan kuesioner. Pengolahan data dengan komputerisasi, menggunakan uji Chi-quare dengan tingkat kemaknaan 0,05. Kesimpulan Ada hubungan antara pengetahuan, dukungan suami dengan pemilihan metode kontrasepsi jangka panjang (MKJP).

Artikel Penelitian yang diteliti oleh [11] yang berjudul "Faktor yang Berhubungan dengan Penggunaan Metode Kontrasepsi Jangka Panjang (MKJP) di Desa Teupin Raya Peusangan Siblah Krueng Kabupaten Bireuen" menggunakan metode penelitian yang digunakan adalah analitik cross sectional, yang dilakukan pada tanggal 10 Juli 2018. Populasi dalam penelitian ini yaitu seluruh akseptor KB yang ada di Desa Teupin Raya Kecamatan Peusangan Siblah Krueng Kabupaten Bireuen. Tehnik pengambilan sampel yaitu dengan cara total populasi sebanyak 41 orang. Jenis data yang digunakan dalam penelitian ini adalah data primer dan data sekunder. Metode pengelohan data collecting, checking, coding, entering dan processing. Analisis data yang digunakan adalah analisis univariat dan analisis bivariat dengan uji chi-square. Kesimpulan ada pengaruh antara sosial budaya terhadap rendahnya penggunaan MKJP di Desa Teupin Raya Kecamatan Peusangan Kabupaten Bireuen serta tidak pengaruh pengetahuan, dan peran tenaga kesehatan, terhadap rendahnya penggunaan MKJP di Desa Teupin Raya Kecamatan Peusangan Kabupaten Bireuen Tahun 2018.

Artikel Penelitian yang diteliti oleh [12] yang berjudul "Faktor Yang Mempengaruhi Wanita PUS Terhadap Pemilihan Metode Kontrasepsi Jangka Panjang (MKJP) Di Puskesmas Mayor Umar Damanik Kecamatan Tanjungbalai Selatan Kota Tanjung balai” 


\section{Vol. 16 No.2 Mei - Agustus 2021}

menggunakan metode penelitian survei analitik dengan pendekatan cross sectional. Populasi adalah seluruh ibu wanita PUS sebanyak 1.984 orang dan sampel yang diambil secara accidental sampling sebanyak 95 orang. Analisa data secara univariat, bivariat dan multivariat. Analisis data dilakukan secara univariat, bivariat menggunakan analisis Chis quare pada batas kemaknaan perhitungan statistik $p$ value $(0,05)$, multivariat dilakukan dengan uji regresi logistik.

Kesimpulan ada pengaruh pengetahuan dan sikap terhadap pemilihan MKJP di Puskesmas Mayor Umar Damanik Kecamatan Tanjung balai. Selatan Kota Tanjungbalai.

\section{HASIL DAN PEMBAHASAN}

Artikel Dari hasil literature review yang telah dipaparkan Adanya pengaruh pengetahuan, fasilitas kesehatan, dukungan suami, dan budaya dengan pemilihan alat kontrasepsi jangka Panjang(MKJP) untuk pasangan Usia subur. Asumsi peneliti, peran serta tenaga medis dalam kategori aktif, namun pemakaian Metode Kontrasepsi Jangka Panjang (MKJP) masih sedikit dikarenakan petugas medis hanya menjelaskan dan memperkenalkan Metode Kontrasepsi Jangka Panjang (MKJP). Namun untuk keputusan pemilihan alat KB tetap ditangan akseptor sendiri. Namun demikian, meskipun tenaga kesehatan aktif dalam mempromosikan, budaya setempat sangat melatar belakangi susksesnya pemakaian Metode Kontrasepsi Jangka Panjang (MKJP) atau tidak.

Tenaga kesehatan adalah setiap orang yang mengabdikan diri dalam bidang kesehatan serta memiliki pengetahuan dan/atau keterampilan melalui pendidikan di bidang kesehatan untuk jenis tertentu memerlukan kewenangan untuk melakukan upaya kesehatan. Tenaga kesehatan dalam hal ini berperan sebagai pemberi pelayanan $\mathrm{KB}$ dengan melakukan penanganan sesuai dengan efek samping yang muncul dari akseptor. Peran yang baik dalam menangani efek samping berdampak positif pada teratasinya keluhan efek samping yang dirasakan ibu, sebaliknya peran yang kurang dari tenaga kesehatan berdampak pada efek samping yang tidak tertangani dan masih dialami oleh ibu. Selain itu kemungkinan dropout dalam menjadi akseptor KB sangat mungkin terjadi akibat dari efek samping yang dialami oleh ibu.

Peran serta yang baik dari tenaga kesehatan setempat dilakukan melalui kegiatan promotif yaitu melalui konseling, penyuluhan kelas ibu, maupun pasangan usia subur di pelayanan kesehatan. Tenaga kesehatan setempat Journal of Healthcare Technology and Medicine Vol. 4 No. 2 Oktober 2018 memiliki peran yang baik karena mampu memberikan perubahan hasil yang positif bagi lingkungan setempat, hal ini dapat diperkuat dari adanya data dukung penunjang seperti data pencatatan, serta perubahan yang dapat dilihat secara langsung.
Pengetahuan memiliki pengaruh secara signifikan terhadap pemilihan MKJP di Puskesmas Mayor Umar Damanik Kecamatan Tanjung balai Selatan Kota Tanjung balai tahun 2019. Hasil OR pada variabel pengetahuan menunjukkan nilai OR 16,291. Artinya pengetahuan yang kurang baik cenderung 16 kali lipat memiliki pengaruh terhadap tidak memilihnya MKJP pada wanita PUS. Oleh karena nilai B bernilai positif, maka pengetahuan mempunyai pengaruh positif terhadap pemilihan MKJP. Penelitian ini sejalan dengan penelitian yang dilakukan oleh Setiasih, dkk tahun 2013 tentang Analisis Faktor-faktor yang Mempengaruhi Pemilihan Metode Kontrasepsi Jangka Panjang (MKJP) pada Wanita Pasangan Usia Subur (PUS) di Kabupaten Kendal, menunjukkan bahwa ada hubungan antara pengetahuan dengan pemilihan Metode Kontrasepsi ( $\mathrm{p}$ value $=0.034$ ) (15). Penelitian ini juga sejalan dengan penelitian yang dilakukan oleh Mahmudah tahun 2015 tentang Analisis Faktor yang Berhubungan DenganPemilihan Metode Kontrasepsi Jangka Panjang (MKJP)

Pada Akseptor KB Wanita di Kecamatan Banyubiru Kabupaten Semarang, menunjukkan bahwa variabel yang berhubungan dengan pemilihan MKJP adalah pengetahuan ( $\mathrm{sig}=0,001)$, dengan pemilihan MKJP (16). Pengetahuan responden yang tinggi dapat menggambarkan wawasan yang lebih luas sehingga memudahkan dalam menerima inovasi baru dan pengambilan keputusan yang sesuai. Tingkat pengetahuan seseorang yang tinggi, selain dikarenakan tingkat pendidikan yang tinggi, juga dipengaruhi oleh keaktifan seseorang dalam mencari informasi. Pengetahuan seseorang dapat diperoleh dari keikutsertaan dalam kegiatan-kegiatan, misalnya penyuluhan rutin mengenai alat kontrasepsi.

\section{SIMPULAN DAN SARAN}

\section{Simpulan}

Berdasarkan literature review yang telah dilakukan oleh penulis, maka dapat ditarik suatu kesimpulan bahwa Adanya pengaruh pengetahuan, sikap, fasilitas kesehatan, dukungan suami, motivasi, dan budaya dengan pemilihan alat kontrasepsi jangka Panjang (MKJP) untuk pasangan Usia subur. Saran yang dapat diberikan untuk pelaksanaan literature review selanjutnya adalah Kepada akseptor dan calon akseptor untuk memilih metode kontrasepsi sesuai dengan kenyamanan diri, bukan atas dorongan orang lain.

Kesimpulan diperoleh bahwa ada pengaruh pengetahuan, fasilitas kesehatan, dukungan, dan budaya terhadap pemilihan MKJP Diharapkan dapat dijadikan sebagai bahan informasi bagi Puskesmas atau Instansi untuk meningkatkan penggunaan MKJP pada wanita PUS dengan cara pemberian penyuluhan secara tepat dan jelas di lingkungan masyarakat agar 
masyarakat dapat mengetahui secara jelas tentang manfaat, jenis, dan keuntungan menggunakan alat MKJP pada wanita PUS.

\section{Saran}

Disarankan kepada akseptor untuk dapat meningkatkat pemahaman terhadap penggunaan MKJP sehingga mau diterima oleh sosial budaya setempat dalam rangka upaya yang signifikan, guna meningkatkan cakupan penggunaan metode kontrasepsi Jangka Panjang (MKJP).

\section{DAFTAR PUSTAKA}

[1] B. Hardhana, D. Budijanto, V. Sitohang, and T. A. Soenardi, Profil kesehatan Indonesia, 2012. Pusat Data dan Informasi, Kementerian Kesehatan Republik Indonesia, 2013.

[2] R. Kurniawan, Profil kesehatan Indonesia tahun 2018. Kementerian Kesehatan RI, 2019.

[3] L. Triyanto and D. Indriani, "Faktor yang mempengaruhi penggunaan jenis Metode Kontrasepsi Jangka Panjang (MKJP) pada wanita menikah usia subur di Provinsi Jawa Timur," Indones. J. Public Heal., vol. 13, no. 2, pp. 244-255, 2018.

[4] S. Notoatmodjo, "Ilmu perilaku kesehatan," 2010.

[5] D. Flassy, A. L. Rantetampang, Y. Msen, and A. Mallongi, "Factors Affecting of Used Long Contraception Method to Women Reproductive at Public Health Centre Limau Asri Mimika Regency," Education, vol. 81, no. 19, p. 81, 2018.

[6] C. Rahmatiqa and H. Patricia, "Dominant factors on selection of contraception toward new family planning acceptors in public health center area in Padang," Int. J. Community Med. Public Heal., vol. 7, no. 6, p. 2100, 2020.

[7] R. C. Apalem, A. L. Rantetampang, S. Makaba, and A. Mallongi, "The Factors Affecting to Selection of Long Term Contraception Method in Lush Age Couples in Prafi Health Primary Manokwari District West Papua Province," Indexing/Abstracting.

[8] P. Harini, A. Lusiana, and S. Widatiningsih, "The Influence Of Health Education Toward The Level Of Knowledge And Motivation In The Use Of Family Planning Programs With The Long-Term Method Of Contraception," Midwifery Nurs. Res., vol. 1, no. 2, pp. 96-104, 2019.

[9] S. Wardani and E. Fitria, "The Factors Correlating to the Usage of Long-Term Contraception Method (MKJP) Especially IUD in the Domain of Society Health Center Simpang Baru Pekanbaru City," KnE Life Sci., pp. 27-37, 2019.

[10] W. Mayasari, A. Tuharea, and F. Palisoa,
"Faktor-Faktor Yang Berhubungan Dengan Rendahnya Minat Ibu Tentang Penggunaan Metode Kontrasepsi Jangka Panjang Pada Kawasan Pesisir Desa Luhu Kecamatan Huamual Kabupaten Seram Bagian Barat Tahun 2018," Glob. Heal. Sci., vol. 3, no. 4, pp. 334-338, 2018.

[11] M. Misrina and F. Fidiani, "Faktor yang Berhubungan dengan Penggunaan Metode Kontrasepsi Jangka Panjang (MKJP) di Desa Teupin Raya Peusangan Siblah Krueng Kabupaten Bireuen Tahun 2018," J. Healthc. Technol. Med., vol. 4, no. 2, pp. 176-186, 2018.

[12] R. Rismawati, A. Asriwati, J. T. Sibero, and A. J. Hadi, "Faktor Yang Mempengaruhi Wanita PUS Terhadap Pemilihan Metode Kontrasepsi Jangka Panjang (MKJP) Di Puskesmas Mayor Umar Damanik Kecamatan Tanjungbalai Selatan Kota Tanjungbalai," MPPKI (Media Publ. Promosi Kesehat. Indones. Indones. J. Heal. Promot., vol. 3, no. 2, pp. 100-105, 2020. 